\title{
Hepatit Delta Virüs ile Enfekte Hastalarda Hepatit E Seroprevalansı
}

\section{Hepatitis E Virus Seroprevalencein Patients with Hepatitis Delta Virus Infection}

\author{
${ }^{1}$ Aysun ÖZEL YEŞILYURT, ${ }^{2}$ Arzu AYRALER, ${ }^{3}$ Selim TURFAN, \\ ${ }^{4}$ Ahmet Cumhur DÜLGER, ${ }^{4}$ Muhammed Ali AYVAZ \\ ${ }^{1}$ Muradiye State Hospital, Department of Internal Medicine, Van, Turkey \\ ${ }^{2}$ Giresun University Ilhan Ozdemir Traİning and Research Hospital, Department of Family Medicine, Giresun,Turkey \\ ${ }^{3}$ Giresun University Ilhan Ozdemir Traİning and Research Hospital, Department of Emergency Medicine, Giresun, Turkey \\ ${ }^{4}$ Giresun University Ilhan Ozdemir Traİning and Research Hospital, Department of Gastroenterology and Hepatology, Giresun, Turkey
}

\author{
Aysun Özel Yeşilyurt: https://orcid.org/0000-0001-6263-8817 \\ Arzu Ayraler: https://orcid.org/0000-0002-5244-7571 \\ Selim Turfan: https://orcid.org/0000-0003-3524-2512 \\ Ahmet Cumhur Dülger: https://orcid.org/0000-0002-9328-5185 \\ Muhammed Ali Ayvaz: https://orcid.org/0000-0003-4575-2866
}

\begin{abstract}
ÖZ
Amaç: $\mathrm{Bu}$ çalışmanın amacı özellikle HDV ile enfekte hastalarda HEV enfeksiyonunun epidemiyolojik, biyokimyasal ve virolojik özelliklerini açığa çıkarmaktır. Ayrıca HDV enfeksiyonunun HEV seroprevalansı üzerine etkisini, her iki hastalığında endemik olduğu Van ilinde araştırdık.

Materyal ve Metot:2015 Mayıs ve 2018 Mayıs ayları arasinda 3.basamak hastanemize başvuran 198 vakaretrospektif olarak incelendi. Epidemiyolojik veriler, biyokimyasal, serolojik ve virolojik testlerin sonuçları kaydedildi.

Bulgular: Araştırmamızda kronik HDV enfeksiyonlu hastalarda kronik HBV enfeksiyonlulara göre hem anti-HEV IgG hem de anti-HEV IgM düzeyleri daha yüksekti(sırasıyla \% 77'ye karş1 $\% 44, p=0,001$ ve $\% 23$ 'e karş1 \%6, p=0,003) Ayrica Kronik HDV enfeksiyonlu hastalarda kronik HBV enfeksiyonlulara göre daha yüksek AST $(49 \pm 34$ 'e karşı $26 \pm 12 \mathrm{U} / \mathrm{L}, \mathrm{p}=0,005)$ ve ALT $(45 \pm 27$ 'ye karş1 $28 \pm 15$, $\mathrm{p}=0,001)$ seviyeleri ile daha düşük trombosit $\left(159000 \pm 91000\right.$ 'e karş1 $\left.223000 \pm 69000 / \mathrm{mm}^{3}, \mathrm{p}<0,001\right)$ ve serum albumin $(3,8 \pm 0,8$ 'e karşı $4,2 \pm 0,3 \mathrm{mg} / \mathrm{dl}, \mathrm{p}<0,001)$ seviyeleri gözlemlendi.

Sonuç: Aynı çevresel koşullardan ötürü HDV enfeksiyonunun bulunuşu HEV enfeksiyonu yayılımı için major bir risk faktörüdür. Biz bozulmuş karaciğer durumuna bağlı olarak hastalığın yayılımında HDV enfeksiyonlu hastaların hatrı sayılır bir rolü olduğu sonucunu çıkarıyoruz. Ek olarak delta hepatiti özellikle 45 yaş üstü hastalarda önemli bir halk sağlığı problemi olarak devam etmektedir. Hastalığın tedavi başarısına yön vermesi için daha geniş ölçekli çalışmalara ihtiyaç vardır.

Anahtar kelimeler: Hepatit B virüs, hepatit D virüs, hepatit Delta virüs, hepatit E virüs, seroprevalans
\end{abstract}

\section{ABSTRACT}

Objective: The current study was conducted in order to reveal the epidemiologic, biochemical and virologic properties of the HEV cases particularly in patients with HDV infection. We also analysed the impact of HDV infection on HEV seroprevalence in Van region of eastern part of Turkey where the both diseases are still endemic.

Materials and Methods: 198 individuals that admitted to a tertiary hospital in the period of between May 2015 and May 2018 were retrospectively examined. Epidemiologic data, results of the biochemical, serologic and virologic tests were recorded.

Results:Our analysis proved higher seroprevalence both of Anti HEV Ig G and anti HEV Ig M in most patients hospitalised with chronic HDV infection than in patients with chronic HBV infection (77\% versus $44 \%$; $p=0.001$ and $23 \%$ versus $6 \% ; \mathrm{p}=0.003$, respectively). We also noticed that there were higher levels of AST (49 \pm 34 versus $26 \pm 12 \mathrm{U} / \mathrm{L}$; $\mathrm{p}=0.005)$ and ALT $(45 \pm 27$ versus $28 \pm 15 \mathrm{U} / \mathrm{L} ; \mathrm{p}=0.001)$ and lower levels of platelet $(159.000 \pm 91.000$ versus $\left.223.000 \pm 69.000 / \mathrm{mm}^{3} ; \mathrm{p}<0.001\right)$ and serum albumin ( $3.8 \pm 0.8$ versus $4.2 \pm 0.3 \mathrm{mg} / \mathrm{dl}$; $\mathrm{p}<0.001$ ) in chronic HDV patients than in chronic hepatitis B patients.

Conclusion: Presence of HDV infection is a major risk factor for spreading HEV infection because of same environmental conditions. We conclude that patients with HDV infection have a considerable role in the transmission of the disease due to impaired liver condition. Additionally, delta hepatitis remains a serious health concern particularly in patients older than 45 years. Larger case series are needed to accurately guide in the success of the disease treatment. Keywords: Hepatitis B virus, hepatitis D virus, hepatitis Delta virus, hepatitis E virus, seroprevalence

\section{Sorumlu Yazar / Corresponding Author:}

Selim TURFAN

Teyyaredüzü Mah.Atatürk Blv. No:323, 28200 Merkez/Giresun

Phone:04543102000

Mobile Phone:05066921719,

E-mail: dr.selimturfan@hotmail.com
Yayın Bilgisi / Article Info:

Gönderi Tarihi/ Received:27/10/2018

Kabul Tarihi/ Accepted: 26/08/2019

Online Yayın Tarihi/ Published: 31/03/2020 
Atıf/ Cited: Ozel Yesilyurt A, et al. Hepatitis E Virus Seroprevalencein Patients with Hepatitis Delta Virus Infection. Online Türk Sağllk Bilimleri Dergisi 2020;5(1):1-7. doi: 10.26453/otjhs.475340.

\section{INTRODUCTION}

Hepatitis D virus (HDV) is a small, defective hepatotrophic RNA virus which requires the help of hepatitis $\mathrm{B}$ virus (HBV) for its replication. It has been showed that chronic HBV and HDV coinfection cause more severe liver damage than those with chronic HBV infection alone. ${ }^{1}$

Highest HDV prevalence is seen in the mediterranean basin, parts of southern America and Eastern Europe. In contrast to Asia, Africa, and parts of Europe, hepatitis D is not considered as an endemic disease in the United States where only people who inject drugs (PWID) have a high risk of acquiring infection with $\mathrm{HDV}^{2}$

Chronic HDV infection affects approximately $20 \%$ of individuals with hepatitis B infection in the eastern part of Turkey, ultimately leading to fibrosis, cirrhosis and hepatocellular carcinoma. ${ }^{3}$

Hepatitis E virus infection is a significant cause of acute hepatitis in Asia and Africa where the seroprevalence of anti-HEV antibody is about $40 \%{ }^{4}$

Outbreaks and sporadic cases of hepatitis E, presenting as an acute hepatitis have been observed in several countries of the Indian subcontinent, in Asia, and Africa.HEV is an endemic, primarily zoonotic infection in the U .S .and Western Europe. ${ }^{5}$

Hepatitis E virus has 4 genotypes; genotype 1 and 2 are caused life threatening infections in persons $15-$ 30 years of age, with pregnant women being the most likely to risk of acute liver failure. For genotype 3 and 4, most infections occur in those of age 40-60 years, with males representing a large portion of those with severe disease. ${ }^{6}$

The seroprevalence of HEV infection has reported as $7-8 \%$ in pregnant women, $13 \%$ in chronic HBV patients, $54 \%$ in chronic HCV patients in Turkey. ${ }^{7}$

However, the lack of a simple diagnostic test and unawareness for the disease in rural areas of Asia continues to be a barrier to the diagnosis and prevention of hepatitis E virus. Additionally, the prevalence and significance of HEV in higher risk groups such as those with HDV infection is poorly characterized. Thus, a better understanding of transmission of HEV infection could also reveal the analysis of disease patterns. Here we sought, for the first time, to characterize HEV seroprevalance among patients with chronic HDV infection.

\section{MATERIALS AND METHODS}

Our study was approved by Van Yüzüncü Yıl Uni- versity Ethics Committee on 25.12.2017 (decision no: B.30. 2YYU.0.01.00.00/176). Current study was conducted among HBV mono-infected and HBV/ HDV coinfected patients seeking care at clinical facilities in the District of Van city and surroundingareas. Subjects 18 to 70 years of age were eligible for the study if they had chronic hepatitis delta virus infection (defined HDV Ig G seropositivity by ELISA method) or had chronic hepatitis $B$ infection.Group of selected patients had no evidence of hepatocellular carcinoma (HCC). Patients were excluded if they were co-infected with $\mathrm{HCV}$ or had undergone liver transplantation. Serum levels of HDV RNA were also centrally assessed at starting point of the study. Assessment of HDV infection status was determined using the following laboratory diagnostic algorithm: initial screening was with the enzyme-linked immunosorbent assay (Dia. Pro Diagnostic Bioprobes anti-HDV IgG, Italy) and samples that were anti HDV Ig G positive were considered positive for HDV infection. Positive samples also tested by PCR (Bayer INC) for calculating HDV RNA levels.

Cirrhosis was determined according to a testing hierarchy as follows: results on liver biopsy showing cirrhosis any time before study, with an aspartate aminotransferase to platelet ratio index of more than 2 , and presence of radiologic findings of liver cirrhosis.

Clinical laboratory tests, physical examinations and hepatobiliary ultrasonography were performed at baseline, and during scheduled visits. The primary point was to determine the relationship between HDV infection and HEV seroprevalence. Other important points were clarify the impact of HEV infection in patients with HBV infection as well as normal subjects.

Statistical Analysis: Statistical analyses were performed by using SPSS software (SPSS Inc., Chicago, IL). All parameters were described as mean + SD. P values $<0.05$ were considered as statistically significant.Continuous variables were analyzed by $t$ tests. For non-parametric parametersMann-Whitney $\mathrm{U}$ tests were used. A chi-square test was calculated for thecomparison of discrete variables

\section{RESULTS}

Totaly, 198 subjects ( 85 of them were female) were enrolled for the study. The mean ages of females and males were as follows; respectively $39.71 \pm 14$ 
and $40.85 \pm 14.5$ years. There were no significant gender and age differences between groups (allp $>0.005$ ).

Patients in the studydivided into three groups as seen in Table 1: group one (39 patients; 15 of them female) were patients with chronic HDV infection. In group one patients, 30 (76.9\%) of them had seropositive results for Anti HEV Ig G and 9 (23.1\%) of them had tested positive for anti HEV Ig M. Totally, $22(59.5 \%)$ of group one patients had also liver cirrhosis.

Patients of group two (112 cases, 50 of them were female) had naive chronic hepatitis $\mathrm{B}$ infection. In patients of group two $50(44.6 \%)$ were tested positive for Anti HEV Ig G and 7 (6.2\%) had positive results for anti HEV Ig M.

Subjects in control group (47 subjects; 20 were female) were selected from otherwise healthy persons who admitted to internal medicine clinics. There were 17 patients (36.2\%) with positive AntiHEVIgG and with 2 patients (4.3\%) with positive Anti HEV IgM. Among subjects tested positive for AntiHEV IgM (18 patients), the HEV RNA was negative in all those IgM-positive samples.

Anti-HEV prevalence was not difference betweensex in univariate analysis. HEV IgG was significantly more common in older $(>60)$ vs .younger $(<60)$ participants $(\mathrm{p}=0$.0047) HEV IgG positivity was significantly more common in older $(>60)$ than younger $(<60)$ participants $(\mathrm{p}=0.0047)$.

Our analysis proved higher rate both of Anti HEV Ig $\mathrm{G}$ and anti HEV Ig M in most patients hospitalised with chronic HDV infection than in patients with chronic HBV infection (76.9\% versus $44.6 \%$; $\mathrm{p}=0.001$ and $23.1 \%$ versus $6.2 \% ; \mathrm{p}=0.003$, respectively). We also noticed that there were higher levels of AST (49 \pm 34 versus $26 \pm 12 \mathrm{U} / \mathrm{L} ; \mathrm{p}=0.005)$ and ALT (45 \pm 27 versus $28 \pm 15 \mathrm{U} / \mathrm{L} ; \mathrm{p}=0.001)$ and lower levels of platelet $(159.000 \pm 91.000$ versus $\left.223.000 \pm 69.000 / \mathrm{mm}^{3} ; \mathrm{p}<0.001\right)$ and serum albumin $(3.8 \pm 0.8$ versus $4.2 \pm 0.3 \mathrm{mg} / \mathrm{dl} ; \mathrm{p}<0.001)$ in chronic HDV patients than in chronic HBV patients as presented in Table 2. Additionally, there was higher rate of liver cirrhosis in patients with chronic HDV infection than those with chronic HBV infected. (22 patients; $59.5 \%$ versus 16 patients; $14.3 \%$; $<<0.001$ ). Whereas majority of patients tested positive for anti HEV Ig M were came from rural areas of the city ( $61 \%$ versus $38 \% ; \mathrm{p}=0.033$ ), there was no significant difference for anti HEV Ig G seropositivity in terms of residential area ( $51 \%$ versus $48 \%$; $p>0.05$ ). The age-adjusted HEV IgG prevalence was signifi- cantly higher than among farmers compared with urban workers.

Analysis of 38 cirrhotic patients also revealed that, $2462.5 \%$ patients tested positive for anti HEV Ig G and $5(14.6 \%)$ patients had positive results for anti HEV Ig M. Liver cirrhosis was associated with seropositive results for anti-HEV Ig G ( $\mathrm{p}=0.028)$. Otherhand, there was no significant association between liver cirrhosis and anti HEV Ig M seropositivity $(p=0.097)$.

\section{DISCUSSION AND CONCLUSION}

In this study we determined the seroprevalence of anti-HEV antibodies in three different population groups and explored main risk factors. There is insufficient data regarding HEV infection seroprevalence in patients with chronic HBV infection, neither in the subjects with chronic HDV infection, nor in the cirrhotics. Current study revealed that HEV seropositivity was significantly associated with chronic HDV infection, increased age, living in rural areas and elevated liver enzymes.

Globally, HEV infection may probably cause as many as 20 million infections annually, resulting in more than 50.000 deaths mostly due to acute liver failure. HEV infection presents a significant public health problem in Asia and Africa where environmental conditions are detoriated and lack of infrastructure is evident. ${ }^{8}$ Most of the cases with acute viral hepatitis is caused by HEV (HEV genotype 1 or 2) in developing countries, with fulminant liver failure in pregnant women, but co-infection with HEV genotype 3 or 4 may lead to chronic HEV infection in immunocompromised or immunosuppressed patients which is characterized by elevated liver transaminases.A substantial number of persons with incident hepatitis E were identified in subjects who reside in rural areas of Asia, particularly in India. Currently there are no specific treatment regimens for HEV infected patients. ${ }^{9}$

Recent data from Germany suggests that approximately $15 \%$ of the population has been exposed as evidenced by serologic testing. ${ }^{10}$ Although the seroprevalence of HEV varies greatly in different geographic areas, HEV exposure has reportedly been higher in those with chronic HBV infection than has been reported in general population surveys. ${ }^{11}$

On the therhand, HDV is a small circular enveloped RNA virus that can survive only in the presence of $\mathrm{HBV}$ since it requires the HBV and surface antigen for transmission and replication. HDV infection is becoming a major global health burden, with in- 
creasing prevalence and incidence worldwide. Globally 15-20 million people have been coinfected with the HDV and HBVviruses. ${ }^{12}$

Eastern part of Turkey is still highly endemic for HDV infection. Van province in Turkey and surrounding areas have been considered as one of the most low income areas in country and have also high prevalence of HDV. ${ }^{3}$ Recent publications indicate that hepatitis E seroprevalence in Turkey is still high. In the Turkish people prevalence is lower than in Far East but still significantly higher than in western world. While national HEV sero-prevalence estimates in the Turkey range from $7 \%$ to $35 \%$, HEV surveillance data of the Iranian border of Turkey does not currently exist. ${ }^{7}$

Some series have also described higher rates of HEV infection in those with HCV and/or HIV, but data in HDV are lacking. ${ }^{13}$ In the current study, $36.2 \%$ of healthy subjects had tested positive for anti HEV Ig $\mathrm{G}$ and the prevalence of HEV seropositivity was $44.6 \%$ among participants who were ever infected with HBV (HBV surface antibody positive) and $76.9 \%$ in HDV Ag-positive. In the absence of any trials searching HEV infection in HDV patients, our results show increased HEV seroprevalence among patients with HDV infection.

Second, we found that anti HEV Ig M seropositivity was significantly more prevalent in subjects who came from rural areas of the city. This suggests that socioeconomic conditions were determinants of the higher rates. Previous studies performed at tertiary care centers have shown that there were socioeconomic disparities in seroprevalence of HEV infection. Studies also showed that key driver pathways for $\mathrm{HEV}$ infection were as follows: living in rural areas, close contact with pigs and having low socioeconomic status. ${ }^{14}$ Similar to the findings regarding HEV seroprevalence in the other studies, farmers and males had also higher rates of HEV antibodies in the current study. This finding may be due to low sanitary standarts in rural areas of the country.

Anti-HEV IgG are common in the Italian general population and even more so in Liver transplated (LT) patients or patients with chronic HCV or HBV infection. Additionally, they also found increased seroprevalence of HEV IgG in subjects infected with HIV, on hemodialysis and solid-organ transplant recipients. ${ }^{15}$

Chronic HEV infection is not restricted to solid organ transplant recipients but can also occur in immunosuppressed patients with hematological or rheumatologicaldisease. ${ }^{16}$ In this retrospective study, we found that chronic HEV infection mostly seen in patients with cirrhosis. Although we observed higher HEV Ig G prevalence in the cirrhotic group than in the control group, we did not find a significant difference between the two groups in anti HEV Ig M seropositivity.

This study has several limitations. Although we enrolled subjects from a unique delta hepatitis population, our sample was limited to one hospital of the country. Second, because the trial designed to collect data from electronic medical records, we were not able to obtain detailed medical history of the participants.

In conclusion; HEV exposure is higher in subjects living in rural areas than has been reported in urban population. These data also demonstrate that HEVinfection is prevalent among those with HDV infection and may be related to the presence of liver cirrhosis.

Ethics Committee Approval: Our study was approved by Van Yüzüncü Y1l University Ethics Committee on 25.12.2017 (decision no: B.30. 2YYU.0.01.00.00/176)

Conflict of Interest: No conflict of interest was declared by the authors.

Author Contributions: Concept - A.Ö.Y. A.C.D.; Supervision - A.C.D.; Materials - A.Ö.Y.; Data Collection and/or Processing -A.Ö.Y. Analysis and/ or Interpretation- A.Ö.Y A.A. S.T A.C.D M.A.A ; Writing - A.Ö.Y S.T A.A

Peer-review: Externally peer-reviewed..

\section{REFERENCES}

1. Noureddin M, Gish R. Hepatitis Delta: Epidemiology, Diagnosis and Management 36 Years After Discovery.CurrGastroenterol Rep. 2014;16:365.

2. Safaie P, Razeghi S, Rouster SD, Privitera I, Sherman KE. Hepatitis D diagnostics: Utilization and testing in the United States. Virus Res. 2018;250:114-117.

3. Dulger AC, Suvak B, Gonullu H, et al. High prevalence of chronic hepatitis $\mathrm{D}$ virus infection in Eastern Turkey: urbanization of the disease. Arch Med Sci. 2016;12(2):415-20.

4. Bai MJ, Zhou N, Dong W, Li GX, Cong W, Zhu XQ. Seroprevalence and risk factors of hepatitis $\mathrm{E}$ virus infection in cancer patients in eastern China.Int J Infect Dis. 2018;71:42-47.

5. Hofmeister MG, Foster MA, Teshale EH. Epidemiology and Transmission of Hepatitis A 
Virus and Hepatitis E Virus Infections in the United States.Cold Spring HarbPerspect Med. 2018.doi: 10.1101/cshperspect.a033431.

6. Dalton HR, Izopet J. Transmission and Epidemiology of Hepatitis E Virus Genotype 3 and 4 Infections. Cold Spring HarbPerspect Med. 2018.doi: 10.1101/cshperspect.a032144.

7. Leblebicioglu H, Ozaras R. Hepatitis E virus infection in Turkey: a systematic review. Ann ClinMicrobiolAntimicrob. 2018;17(1):17.

8. Nan Y, Wu C, Zhao Q, Zhou EM. Zoonotic Hepatitis E Virus: An Ignored Risk for Public Health. Front Microbiol. 2017;8:2396.

9. Pérez-Gracia MT, Suay-García B, MateosLindemann ML. Hepatitis E and pregnancy: current state Rev Med Virol. 2017. doi: 10.1002/rmv.1929. [Epub ahead of print].

10. Faber $M$, Willrich $N$, Schemmerer $M$, et al.Hepatitis $\mathrm{E}$ virus seroprevalence, seroincidence and seroreversion in the German adult population. J Viral Hepat. 2018. doi: 10.1111/ jvh.12868. [Epub ahead of print].

11. Zhang L, Jiang Z, Lv J, et al. Comparison of hepatitis $\mathrm{E}$ virus seroprevalence between HBsAg-positive population and healthy controls in Shandong province, China. BMC Infectious Diseases. 2018;18:75.

12. Wranke A, PinheiroBorzacov LM, Parana R, et al. Clinical and virological heterogeneity of hepatitis delta in different regions world-wide: The Hepatitis Delta International Network (HDIN). Liver Int. 2018;38(5):842-850.

13. López-Fabal MF, Gómez-Garcés JL. Seroprevalence of hepatitis $\mathrm{E}$ virus in patients with hepatitis $\mathrm{C}$ and / or infected with HIV. Rev EspQuimioter. 2015;28(6):314-316.

14. Halánová M1, Veseliny E2, Kalinová Z, et al. Seroprevalence of Hepatitis E Virus in Roma Settlements: A Comparison with the General Population in Slovakia. Int J Environ Res Public Health. 2018;15(5):904.

15. Kamar N, Abravanel F, Selves J, et al. Influence of immunosuppressive therapy on the natural history of genotype 3 hepatitis-E virus infection after organ transplantation. Transplantation. 2010;89:353-360.

16. Tavitian S, Peron JM, Huguet F, et al. Ribavirin for chronic hepatitis prevention among patients with hematologic malignancies. Emerg Infect Dis. 2015;21:1466-1469. 
Table 1. Serologic results of the three groups.

\begin{tabular}{|l|c|c|c|c|}
\hline & & $\begin{array}{l}\text { Chronic } \\
\text { HDV group }\end{array}$ & $\begin{array}{l}\text { Naive HBV } \\
\text { group }\end{array}$ & $\begin{array}{l}\text { Control group } \\
\text { (Healthy persons) }\end{array}$ \\
\hline \multirow{2}{*}{ Total } & & 39 & 112 & 47 \\
\hline \multirow{2}{*}{ Female } & & 15 & 50 & 20 \\
\hline Male & & 24 & 62 & 27 \\
\hline $\begin{array}{l}\text { Anti HEV } \\
\text { IgM }\end{array}$ & + & $9(23.1 \%)$ & $7(6.2 \%)$ & $2(4.3 \%)$ \\
\cline { 2 - 5 } & - & $30(76.9 \%)$ & $105(93.8 \%)$ & $45(95.7 \%)$ \\
\hline $\begin{array}{l}\text { Anti HEV } \\
\text { IgG }\end{array}$ & + & $30(76.9 \%)$ & $50(44.6 \%)$ & $17(36.2 \%)$ \\
\cline { 2 - 5 } & - & $9(23.1 \%)$ & $62(55.4 \%)$ & $30(63.8 \%)$ \\
\hline \multirow{2}{*}{$\begin{array}{l}\text { Liver cir- } \\
\text { rhosis }\end{array}$} & + & $23(59.5 \%)$ & $16(14.3 \%)$ & \\
\cline { 2 - 5 } & - & $16(40.5 \%)$ & $96(85.7 \%)$ & \\
\hline
\end{tabular}

$+=$ positive; $-=$ negative 
Table 2. Biochemically comparing of naive HBV group and chronic HDV group.

\begin{tabular}{|c|c|c|c|c|c|c|}
\hline & & $\mathbf{N}$ & Mean \pm Std Deviation & Minimum & Maximum & $\mathbf{p}$ \\
\hline \multirow{2}{*}{ ALT } & Delta negative & 111 & $28.11 \pm 15.522$ & 7 & 93 & \multirow{2}{*}{0.001} \\
\hline & Delta positive & 39 & $45.08 \pm 27.236$ & 6 & 119 & \\
\hline \multirow{2}{*}{ AST } & Delta negative & 110 & $26.48 \pm 12.198$ & 11 & 94 & \multirow{2}{*}{0.009} \\
\hline & Delta positive & 39 & $49.00 \pm 34.805$ & 15 & 195 & \\
\hline \multirow{2}{*}{ INR } & Delta negative & 104 & $1.056 \pm 0.2807$ & 0.8 & 3.4 & \multirow{2}{*}{0.159} \\
\hline & Delta positive & 39 & $1.154 \pm 0.2723$ & 0.9 & 2,0 & \\
\hline \multirow{2}{*}{ AFP } & Delta negative & 106 & $31.964 \pm 197.8335$ & 0.7 & 2000.0 & \multirow{2}{*}{0.756} \\
\hline & Delta positive & 38 & $19.929 \pm 70.9268$ & 1.0 & 420.0 & \\
\hline \multirow{2}{*}{ Platelet } & Delta negative & 111 & $223459 \pm 69937.736$ & 36000 & 391000 & \multirow{2}{*}{0.001} \\
\hline & Delta positive & 39 & $159435 \pm 91811.533$ & 28000 & 452000 & \\
\hline \multirow{2}{*}{ Albumin } & Delta negative & 109 & $4.23 \pm 0.3891$ & 2.2 & 4.9 & \multirow{2}{*}{0.001} \\
\hline & Delta positive & 38 & $3.82 \pm 0.8014$ & 1.5 & 4.8 & \\
\hline \multirow{2}{*}{ Calcium } & Delta negative & 79 & $9.251 \pm 0.5351$ & 7.6 & 10.3 & \multirow{2}{*}{0.197} \\
\hline & Delta positive & 33 & $11.655 \pm 14.6248$ & 6.7 & 93.0 & \\
\hline
\end{tabular}

